\title{
THE THANKSGIVING MEETING IN AMES
}

The three hundred first regular meeting of the Society was held at Iowa State College on Friday and Saturday, November 25-26, 1932. About eighty persons attended the meeting, among whom were the following forty-six members of the Society:

E. S. Allen, J. V. Atanasoff, R. W. Babcock, R. P. Baker, M. A. Basoco, W. C. Brenke, E. W. Chittenden, J. T. Colpitts, N. B. Conkwright, A. T. Craig, M. E. Daniells, H. P. Doole, J. M. Earl, C. W. Emmons, M. G. Gaba, Sister M. de L. Gough, Cornelius Gouwens, F. S. Harper, J. C. Hempstead, G. A. Herr, J. J. L. Hinrichsen, D. L. Holl, Louis Ingold, M. H. Ingraham, Dunham Jackson, H. E. Jordan, D. E. Kearney, J. V. McKelvey, M. M. McKelvey, H. W. March, U. G. Mitchell, I. F. Neff, T. A. Pierce, H. R. Pyle, B. L. Remick, H. L. Rietz, P. G. Robinson, L. L. Runge, M. F. Schmeiser, E. R. Smith, G. W. Smith, H. F. Smith, E. B. Stouffer, L. E. Ward, J. J. Wheeler, Roscoe Woods.

On Friday afternoon, Professor H. W. March gave an address entitled Applications of the theory of elasticity to wood, a material of anisotropic structure. On Saturday morning, Professor E. B. Stouffer spoke to the Society on Some canonical forms and their associated geometries.

On Friday evening a dinner was held at the Memorial Union. About seventy-five persons attended the dinner. The toastmaster was Professor J. V. McKelvey, who first called upon Professor E. R. Smith to give a welcoming address. He then in turn called on Dean R. W. Babcock and Professors W. C. Brenke, U. G. Mitchell, H. L. Rietz, and Dunham Jackson, each of whom gave short addresses. The concluding address was by Dean Charles Friley of Iowa State College who spoke on the relationship of mathematics to science. Immediately preceding the speakers, a musical program was presented by Professor E. S. Allen, and Messrs. C. C. Hurd and C. P. Wells.

On Saturday morning, upon motion of Dean Babcock, the thanks of those present were given to the local committee for the splendid arrangements made for the meeting, and to the invited speakers for their interesting addresses.

Vice-President E. W. Chittenden presided at the meeting on Friday afternoon, and Professor E. R. Smith during the address of Professor March on Friday afternoon. Professor Louis Ingold presided on Saturday morning. 
The titles of papers read at the meeting follow. Those whose abstract numbers are followed by $t$ were read by title. Mr. Brandner was introduced by Professor H. L. Rietz, Mr. Montgomery by Professor E. W. Chittenden, Mr. Robertson by Professor E. S. Allen, and Mr. Wells by Professor J. V. Atanasoff.

1. Distributions of functions of middle items, by Dr.A.T. Craig. (Abstract No. 38-11-274.)

2. A test of the significance of the difference of the correlation coefficients of normal bivariate samples, by Mr. F. A. Brandner. (Abstract No. 38-11-275.)

3. A generalized definition of probability, by Professor E. S. Allen. (Abstract No. 38-11-276.)

4. Sections of point sets, by Mr. Deane Montgomery. (Abstract No. 38-11-277.)

5. The conditions for conformality in the elliptic and hyperbolic geometries, by Professor H. R. Pyle. (Abstract No. 38-11-278.)

6. On the reduction of a matrix to its rational canonical form, by Professor M. H. Ingraham. (Abstract No. 38-11-279.)

7. The fractional differentiation operator, by Mr. Fred Robertson. (Abstract No. 38-11-288.)

8. A technique for the study of the interaction of economic series, by Professor H. T. Davis. (Abstract No. 38-11-280-t.)

9. Certain irregular non-homogeneous lineardifference equations, by Professor David Moskovitz. (Abstract No. 38-11-281-t.)

10. Mutual impedance of long grounded wires when the conductivity of the earth varies exponentially with depth, by Dr. Marion C. Gray. (Abstract No. 38-11-282-t.)

11. The deflection of a rectangular plate, supported at two opposite edges, due to a point load, by Professor D. L. Holl. (Abstract No. 38-11-283.)

12. On the summability and generalized sum of the series of Legendre polynomials $\sum n^{p} X_{n}(x)$, by Professor W. C. Brenke. (Abstract No. 38-11-284.)

13. Problems of approximation with integral auxiliary conditions, by Professor Dunham Jackson. (Abstract No. 38-11-285.)

14. Solution of Dirac's equation without specialization of the operators, by Professor J. V.Atanasoff. (Abstract No.38-11-286.)

15. Separation of partial differential equations in two unknowns, by Mr. C. P. Wells. (Abstract No. 38-11-287.)

M. H. Ingraham, Associate Secretary 